\title{
Gender identity disputed in the court of justice: a story of female to male sexual transformation in the hellenistic period, described by Diodorus Siculus
}

\author{
Anastasia K. Armeni, ${ }^{1}$ Vasiliki Vasileiou, ${ }^{2}$ George Markantes, ${ }^{1}$ Christina Damoulari, ${ }^{1}$ \\ Angelina Mandrapilia, ${ }^{1}$ Fotini A. Kosmopoulou, ${ }^{1}$ Varvara Keramisanou, ${ }^{1}$ \\ Danai Georgakopoulou, ${ }^{1}$ Neoklis A. Georgopoulos ${ }^{1}$
}

${ }^{1}$ Division of Reproductive Endocrinology, Department of Obstetrics and Gynecology, University of Patras Medical School, Patras; ${ }^{2} 1^{\text {st }}$ Department of Endocrinology, Diabetes Centre, "Alexandra" Hospital, Athens; Greece

\begin{abstract}
Cases of sexual reassignment in Greco-Roman antiquity, presenting as a pubertal female to male gender transformation, are described in the "classical" literature. Textual evidence concerning a case of androgynism, garnered by Diodorus Siculus, among other similar accounts, as an odd story of gender dispute in a court of justice, is provided in the present study. A medical interpretation of the data pertaining to this case has been attempted and is herein reported. The spontaneous virilization and post-pubertal gender inversion of the specific individual appears to have been caused by a defect either in $5 \alpha$-reductase type 2 or in $17 \beta$ hydroxysteroid dehydrogenase genes and consequent deficient enzymatic activity.
\end{abstract}

Key words: Ambiguous genitalia, Androgynism, Diodorus Siculus, Disorders of sexual differentiation, Heterosexual puberty, $5 \alpha$-reductase deficiency, $17 \beta$ HSD deficiency

\section{A. LITERAL DOCUMENTATION OF THE HERAIS} STORY: A CASE OF FEMALE TO MALE SEXUAL TRANSFORMATION DESCRIBED BY DIODORUS SICULUS

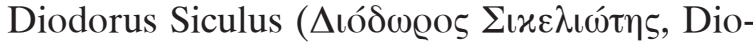
doros Sikeliotes) was a Greek historian and writer, born around 80 B.C. at the foot of the volcano of

\footnotetext{
Address for correspondence:

Neoklis A. Georgopoulos, Department of Obstetrics and Gynecology, Division of Reproductive Endocrinology, University of Patras Medical School, Rio-26500, Greece, Tel.: 2610-999835, Fax: 2610-993854, E-mail: neoklisg@hol.gr Received 31-05-13, Accepted 01-11-13
}

Etna (Aetna) in Agyrium (today Agira) in Sicily. His English translator (1933), Charles Henry Oldfather, remarks on the "striking coincidence" that one of only two known Greek inscriptions from Agyrium (I.G. $\mathrm{XIV}, 588$ ) is the tombstone of "Diodorus, the son of Apollonius". ${ }^{1} \mathrm{He}$ became famous for his monumental universal history, the "Bibliotheca Historica"1-3 (Historical Library) thought to have been written between 60 and 30 B.C. During those 30 years he was engaged in long-distance travels in order to personally collect information on different nations and tribes to be included in his history. This colossal work consisted of 40 books of which fewer than half 
have survived to the present. Fragments of the lost books are preserved in the Library of the Patriarch of Constantinople Photius (858/67-878/86 AD) and as excerpts in works by Constantine Porphyrogenitus. In this enormous epic history, Diodorus sought to incorporate all historical events from the time before the Trojan War until his own era, with special focus on the time of Alexander the Great and his successors. He decided to present his work under the name of "Bibliotheca" in recognition of the fact that he was assembling a composite work deriving from many sources. In the centuries to come, the "Bibliotheca Historica" enjoyed immense reputation and served as a reliable source for a great number of savants in the fields of philosophy, religion and history. It is therefore of particular importance that Diodorus included in his work, among events of such a huge historical significance as the Persian Wars and the decisive battles of Alexander the Great, a testimony of cases of androgynism noted in his era.

In ancient culture, humans possessing both sexes were condemned to extermination as they were regarded as miscreations and evil omens arousing terror. ${ }^{4}$ Being a rationalist, Diodorus, who lived in the age of Caesar, adopted a humanitarian view of the world, interpreting androgynous creatures as mere faults of nature. ${ }^{1}$ By including such cases in his historical work, he endeavoured to familiarize his readers with such events thus eliminating the feeling of dread at their appearance. The same attitude was also followed by other prominent historians and philosophers of his era, including Plinius the Elder, ${ }^{5}$ Phlegon ${ }^{5}$ and Titus Livius. ${ }^{6}$

Among the cases of androgynism collected by Diodorus, the story of Herais (Hoaǐs) is of especial interest, the reason for this being that, to our knowledge, this is the only description of a legal dispute over the gender of a person with ambiguous genitalia ever reported throughout ancient history.

The dating of the event is close to 145 B.C. and, in brief, the sequence of events was the following:

"In a city of Arabia, called Aves, lived a man of Macedonian origin, named Diophantus. He was married to a native woman and they had a daughter named Herais. When Herais was at the proper age, her father married her to a man named Samiades.
Samiades lived with his wife for a year and then went off on a long journey. During his absence, Herais developed a strange illness, characterized by intense inflammation at the base of her abdomen. As the swelling worsened and was also complicated by high fever, the physicians suspected that an ulceration had taken place at the mouth of the uterus. They applied remedies which would reduce the inflammation but on the seventh day, the surface of the swelling cracked and a penis and two testicles appeared in Herais' groin.

When the rupture occurred, with its sequel, neither her physician nor any other visitors were present, but only her mother and two maidservants. Although astonished by this strange phenomenon, the women provided Herais proper care and withheld the truth. Herais, having been relieved of her "illness", continued to wear feminine attire but returned to her father's house.

When Samiades returned, he asked to see his wife. Herais was ashamed and did not dare to appear in front of her husband. Thus, Samiades dragged her father to trial, claiming his wife back. The judges decided that Herais had to follow her husband. It was only then that Herais revealed the truth: mobilizing all her courage, she took off her dress and displayed her masculinity in public, screaming and asking how could some people force a man to live with another man. All present were overcome with astonishment but accepted this unusual fact. As it is said, Herais, after revealing her male nature, exchanged her woman's apparel for the garb of a young man, changed her/ his name to Diophantus and enlisted in the cavalry fighting with the king. ${ }^{2}$ As for Samiades, they say that, constrained by shame for his unnatural marriage, he made his departure from life. Thus, she who was born a woman took on a man's courage and renown, while the man proved to be less strong-minded than a woman."

\section{B. DIFFERENTIAL DIAGNOSIS OF HERAIS' CASE}

Diodorus Siculus described the story of Herais, a case of sexual reassignment, namely a female to male gender role change occurring after marriage and consisting of a female to male phenotypic transition. Herais was raised as female during childhood, was married to a man and subsequently experienced 
a sexual transformation. Given that marriages at that time were frequently agreed upon close to the time of puberty or soon after, the described female to male sexual transformation is in fact a case of heterosexual puberty. Indeed, Diodorus described the appearance of male external genitalia, including a penis-like structure and two testes, through an inflamed hypogastrial hernia. This inflammation was probably caused by a pubertal increase in the size of the testes trapped in the narrow inguinal duct. After this event Herais completely changed his/her gender assignment, rejected femininity and strongly adhered to a reassigned masculinity that led him to completely change his social orientation: he changed his name from feminine to masculine and served as a warrior in the army of the king. We can assume, therefore, that Diodorus described a case of a Disorder of Sexual Differentiation (DSD) which, despite the intra-abdominal presence of both testes, was raised as female during childhood and presented pubertal signs of virilization, leading to heterosexual puberty.

The presence of two testes in Diodorus' description of Herais' case excludes the diagnosis of virilizing adrenal or testicular tumors, gonadal dysgenesis, true hermaphroditism and female pseudohermaphroditism. ${ }^{7}$ Therefore, heterosexual puberty in this particular case will have been the result of an increase in serum androgen levels, produced by testicular tissue, leading to the development of male secondary sex characteristics.

Given that heterosexual puberty has never been reported in Androgen Insensitivity Syndrome (AIS), the most likely diagnosis in cases of female to male transition is a defect in androgen synthesis. Among all enzyme deficiencies in the pathway of testosteroneDHT synthesis are only those of $17 \beta$ hydroxysteroid dehydrogenase (HSD17B3), the enzyme converting androstenedione to testosterone, or $5 \alpha$-reductase type 2 , the enzyme converting testosterone to dihydrotestosterone (DHT). Such defects can lead to similar clinical phenotypes characterized by ambiguous genitalia appearance leading to female sex assignment at birth and heterosexual puberty. ${ }^{7}$

Differential diagnosis between $5 \alpha$-reductase type 2 and HSD17B3 deficiencies cannot be made based on clinical phenotype. $5 \alpha$-reductase type 2 converts testosterone to DHT, the major determinant of male external genitalia formation, and is highly expressed early in gestation in testicular, scrotal and phallic tissues. This undoubtedly makes its action essential for the normal development of male primary sexual characteristics in the fetus. Therefore, lack of expression of this gene leads to decreased production of DHT and development of external genitals in the neonate, simulating those of a female, as in the case of Herais. ${ }^{9}$ Depending on the molecular defect, $5 \alpha$-reductase deficiency may be manifested with a wide spectrum of clinical phenotypes, from milder ones that can be easily overlooked ${ }^{10}$ to more severe ones resembling Herais' case. ${ }^{11}$ HSD17B3 deficiency also results in genital transformation at puberty which can be quite pronounced.

$5 \alpha$-reductase type 2 deficiency promotes more considerable changes during puberty, which are attributed to the accumulated testosterone and its conversion to DHT by type 1 isoenzyme. Unlike $5 \alpha$-reductase type 2 , type 1 is not expressed in utero, therefore contributing to postnatal sexual but not to fetal differentiation. ${ }^{12}$ An age-dependent increase in the expression of the $5 \alpha$-reductase type 1 gene has been reported, rendering its action measurable during puberty and for the remainder of life in peripheral tissues, such as liver and kidney, thus compensating for $5 \alpha$-reductase type 2 deficiency.

Heterosexual puberty in cases of HSD17B3 deficiency is due to isoenzyme HSD17B5. Although HSD17B3 converts androstenedione to testosterone in the testes, HSD17B5 is responsible for extragonadal production of testosterone in peripheral tissues, such as placenta, prostate, adrenals and liver, while it slightly contributes to testosterone produced by the testes. ${ }^{13}$ Furthermore, there is an age-dependent regulatory transcription mechanism concerning HSD17B3 and HSD17B5 isoenzymes, with the former decreasing and the latter increasing with age. ${ }^{14,15}$

Nevertheless, the clinical phenotype of $5 \alpha$-reductase deficiency cannot be clearly distinguished from that of $17 \beta$ hydroxysteroid dehydrogenase deficiency, ${ }^{12}$ and even less so, needless to say, based on historical data. Therefore, in the absence of a definitive molecular diagnosis, Herais' case could be attributed to either a $5 \alpha$-reductase or a $17 \beta$ hydroxysteroid dehydrogenase 
gene deficiency, with the former being more likely.

Finally, both $5 \alpha$-reductase and $17 \beta$ hydroxysteroid dehydrogenase gene deficiencies are encountered in the region of the Eastern Mediterranean. Indeed, recent molecular analysis of cases of $5 \alpha$-reductase type 2 gene deficiency revealed a high incidence of cases in the lands around the Mediterranean Sea, many of them reported in subjects of Arabian and Greek ethnic origin. ${ }^{11}$ Similarly, prevalence of $17 \beta$ hydroxysteroid dehydrogenase gene deficiency is higher among Arabian and Mediterranean populations. ${ }^{16}$

In conclusion, based on the above contemporary appraisal of the case, we could attribute Herais' spontaneous virilization and post-pubertal gender inversion to molecular defects either in $5 \alpha$-reductase type 2 or in $17 \beta$ hydroxysteroid dehydrogenase gene expression and consequent deficient enzyme activity.

\section{REFERENCES}

1. Siculus Diodorus, Booth G (Translator), Valesius H, Rhodomannus I, Ursinus F 1814 The Historical Library of Diodorus the Sicilian in Fifteen Books to which are added the Fragments of Diodorus. London: J. Davis. Downloadable Google Books.

2. Siculus Diodorus, Oldfather CH (Translator), 1935 Library of History: Loeb Classical Library. Cambridge, MA.: Harvard University Press.

3. Siculus Diodorus, Oldfather CH (Translator), 2008 “Library”. Perseus Digital Library. Books pp, 9-17.

4. Luc Brisson 1997 Le sexe incertain: Androgynie et hermaphroditisme dans l'Antiquite gréco-romaine. Paris, Les Belles Lettres.

5. Armeni AK, Vasileiou V, Georgopoulos NA, 2014 When genotype prevails: sexual female-to-male transformation in Classical Antiquity, recorded by Gaius Plinius Secundus and Phlegon. Hormones (Athens) 13: 153-156.
6. Vasileiou V, Armeni AK, Pierris AL, Georgopoulos NA, 2012 Macrosomia and ambiguous genitalia: a long overdue answer to the citizens of Frusino. Hormones (Athens) 11:215-221.

7. Kousta E, Papathanasiou A, Skordis N, 2010 Sex determination and disorders of sex development according to the revised nomenclature and classification in 46, XX individuals. Hormones (Athens) 9: 218-131.

8. Hughes IA, Davies JD, Bunch TI, Pasterski V, Mastroyannopoulou K, MacDougall J, 2012 Androgen insensitivity syndrome. Lancet 380: 1419-1428.

9. Imperato-McGinley J, Zhu YS, 2002 Androgens and male physiology the syndrome of 5alpha-reductase-2 deficiency. Mol Cell Endocrinol 198: 51-59.

10. Skordis N, Shammas C, Efstathiou E, Sertedaki A, Neocleous V, Phylactou L, et al, 2011 Late diagnosis of 5alpha steroid-reductase deficiency due to IVS12A $>$ G mutation of the SRD5a2 gene in an adolescent girl presented with primary amenorrhea. Hormones (Athens) 10: 230-235.

11. Maimoun L, Philibert P, Cammas B, et al, 2011 Phenotypical, Biological, and Molecular Heterogeneity of 5 $\alpha$-Reductase Deficiency: An Extensive International Experience of 55 Patients. J Clin Endocrinol Metab 96: 296-307.

12. Thiele S, Hoppe U, Holterhus PM, Hiort O, 2005 Isoenzyme type 1 of 5alpha-reductase is abundantly transcribed in normal human genital skin fibroblasts and may play an important role in masculinization of 5alpha-reductase type 2 deficient males. Eur J Endocrinol 152: 875-880.

13. George MM, New MI, Ten S, Sultan C, Bhangoo A, 2010 The clinical and molecular heterogeneity of 17ßHSD-3 enzyme deficiency. Horm Res Paediatr 74: 229-240.

14. Hoppe U, Holterhus PM, Wunsch L, et al, 2006 Tissuespecific transcription profiles of sex steroid biosynthesis enzymes and the androgen receptor. J Mol Med 84: 651-659.

15. Faienza MF, Cavallo L, 2012, 17ß-Hydroxysteroid Dehydrogenase Type 3 Deficiency: Diagnosis, Phenotypic Variability and Molecular Findings. Steroids - Basic Science ISBN: 978-953-307-866-3.

16. Rosler A, 200617 beta-hydroxysteroid dehydrogenase 3 deficiency in the Mediterranean population. Pediatr Endocrinol Rev 3: Suppl 3: 455-461. 